\title{
Benign choroidal folds. A case report
}

\section{Pliegues coroideos benignos. Presentación de un caso}

\author{
Mariana Takane-Imay, Robert E. Graciano-Díaz*, Soledad Barlatey and Cristina González-González \\ Ultrasound department, Instituto de Oftalmología Conde de Valenciana, Mexico City, Mexico
}

\begin{abstract}
Objective: To present the clinical and ultrasonographic findings in a patient with benign choroidal folds in the left eye. Method: Case report. Results: A 57-year-old male who sought consultation due to reduced visual acuity, photopsia and nyctalopia. Visual acuity in the right eye was of 20/26 and in the left eye of 20/200, which improved to 20/20 and 20/25 with a pinhole, respectively. Fundoscopy of the left eye showed the presence of horizontal folds and an applied retina. The peripheral retina showed no alterations. Optical coherence tomography showed slightly prominent ripples. Simple computed tomography of the skull ruled out a mass and showed flattening of the posterior wall of the globe. Ultrasonic biometrics in the right eye were of $23.89 \mathrm{~mm}$ and in the left eye of $22.28 \mathrm{~mm}$. B-mode ultrasound showed flattening of the posterior ocular wall and an increased chorioretinal thickness in the macular region of $1.64 \mathrm{~mm}$. Discussion/Conclusion: Choroidal folds are undulations of the surface of the retina, visible by biomicroscopy, and their ultrasonographic feature is flattening of the posterior ocular wall, caused by a diffuse thickening of the sclera and the chorioretinal layer.These eyes have a short axial length compared to the contralateral eye. Ultrasound helps in the diagnosis, being particularly useful for staging chorioretinal thickness and flattening of the posterior ocular wall.
\end{abstract}

Key words: Choroidal folds. Ultrasound. Acquired hyperopia.

\section{Resumen}

Objetivo: Presentación de hallazgos clínicos y ecográficos en un paciente con pliegues coroideos benignos en el ojo izquierdo. Método: Reporte de caso. Resultados: Hombre de 57 años de edad que asiste a consulta por disminución de la agudeza visual, fotopsias y nictalopía. Agudeza visual en el ojo derecho de 20/26 y en el ojo izquierdo de 20/200, las cuales mejoran a 20/20 y 20/25 con agujero estenopeico. La fundoscopia en el ojo izquierdo muestra presencia de pliegues en disposición horizontal y retina aplicada, sin alteraciones en la periferia. Tomografía de coherencia óptica con ondulaciones levemente prominentes. La tomografía computarizada simple de cráneo descarta una lesión ocupativa, y se observa aplanamiento de la pared posterior del globo. La biometría ultrasónica en el ojo derecho es de $23.89 \mathrm{~mm}$ y en el ojo izquierdo de $22.28 \mathrm{~mm}$. En el estudio de ultrasonido modo $B$ se aprecia en el polo posterior rectificación de la pared y aumento de grosor retinocoroideo macular de $1.64 \mathrm{~mm}$. Discusión/Conclusión: Los pliegues coroideos son ondulaciones de la superficie de la retina, son visibles por biomicroscopia, y la característica ecográfica de los pliegues coroideos benignos es el aplanamiento de la pared ocular posterior, que es causada por un engrosamiento difuso de la esclera y de la capa retinocoroidea. Estos ojos presentan una longitud axial corta, comparada con el ojo contralateral. La ecografía ayuda en el diagnóstico de estas entidades, y es particularmente útil para estadificar el grosor retinocoroideo y la rectificación de la pared.

Palabras clave: Pliegues coroideos. Ecografía. Hipermetropía adquirida.

Correspondence:

*Robert E. Graciano-Díaz Chimalpopoca, 14

Col. Obrera, Del. Cuauhtemoc

Date of reception: 05-03-2019

Date of acceptance: 18-07-2019

DOI: 10.24875/RMOE.M20000123
Available online: 01-09-2020 Rev Mex Oftalmol (Eng). 2020;94(5):215-219

www.rmo.com.mx

E-mail: robertgraciano2205@gmail.com

Published by Permanyer. This is an open access article under the CC BY-NC-ND license 2604-1731/@ 2019 Sociedad Mexicana de Oftalm 


\section{Introduction}

The first report was made in 1884 by Nettleship, who described them as "peculiar lines on the choroid" in association with papillitis". Anatomically they are undulations of the retinal pigment epithelium (RPE), Bruch's membrane, and the inner layers of the choroid, which may or may not include the retina. Their cause is the excessive surface area of the choroid in relation to the actual space it occupies.

By fundoscopy, they are observed as deep light and dark bands in relation to the retina. The symptoms associated with choroidal folds can vary, from metamorphopsia and distortion to no symptoms, and frequently patients do not have alterations in the Amsler grid².

The folds are frequently confined to the posterior pole and rarely extend beyond the equator. The patterns they adopt are classified in five varieties: horizontal, oblique, vertical, radial and irregular. Horizontal and oblique are the most typical patterns and are usually parallel. Vertical ones are relatively rare. The characteristics of the folds can help establish their cause ${ }^{3}$.

Angiographically, the folds appear relatively hyperfluorescent because the stretched and thinned retinal pigment epithelium (RPE) facilitates the transmission of choroidal fluorescence. These findings are observed in the early stages of fluorescein angiography (FAG) during choriocapillaris filling. Mode A ultrasound shows axial length shortening. Mode $B$ findings include choroidal thickening (in cases of infiltrative or inflammatory disorders), scleral thickening (in posterior scleritis) or posterior flattening of the eyeball ${ }^{3}$.

The causes of choroidal folds encompass a vast number of widely varying conditions. There are idiopathic ones, discovered as an incidental finding in patients with various refractive defects, emmetropia and even myopia. These are horizontal, symmetrical and occupy the entire posterior pole in asymptomatic patients, and only require observation. In intracranial hypertension, choroidal folds may form prior to the development of papilledema. Some drugs such as topiramate (used for the treatment of epilepsy and migraine) can induce folds that simulate those observed in hypotonia, even with normal intraocular pressure. Diffuse infiltration of the choroid by lymphomas and lymphoid hyperplasia are another cause ${ }^{4}$.

Hypotonia causes extensive, ill-defined, irregular, vertical, or radial folds that originate from the optic nerve. Other findings include cystic macular edema, retinal folds, tortuous vessels, and decreased vision due to foveal involvement ${ }^{5}$.

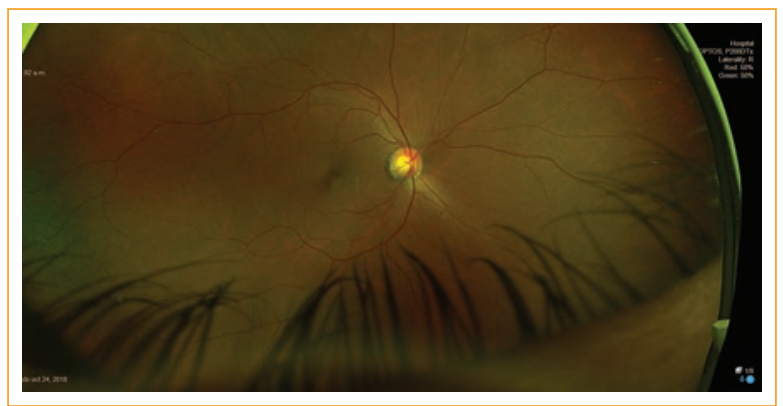

Figure 1. Optos: Clinical picture of the right eye without alterations.

Other causes are complicated surgeries, trauma, ciliary body detachment, and uveitis. Also due to contraction of fibrovascular tissue as part of the remodeling process after an injury. Tumor causes include choroidal tumors like melanomas, metastatic carcinomas, hemangiomas, or osteomas, as well as intraconal and extraconal orbital tumors. Inflammatory causes include posterior scleritis, accompanied by pain, decreased vision, restricted motility and slight proptosis, and other orbital inflammations, such as cellulitis and inflammatory pseudotumor ${ }^{6}$.

Here, we present the case of choroidal folds associated with hyperopia.

\section{Case presentation}

This is a 57-year-old male from the state of Oaxaca, retired, who seeks ophthalmology consultation for the first time due to a 12-month history of decreased visual acuity, photopsia and nyctalopia in the left eye. The patient has no relevant medical history. He has been using eyeglasses for 10 years. Slit-lamp examination of the anterior segment and motility were normal in both eyes. Visual acuity (VA) measured with a Snellen chart was $20 / 60$ in the right eye (OD) and 20/200 in the left eye (OS), and refraction in OD $\left(+1.75-0.75 \times 90^{\circ}\right)$ improved VA to $20 / 20$ and in OS $\left(+3.50-0.75 \times 90^{\circ}\right)$ to $20 / 25$. Intraocular pressure of $12 \mathrm{mmHg}$ in both eyes. Fundus examination was normal in the OD (Figs. 1 and 2), and in the OS it revealed a clear vitreous, round orange optic disc, with well-defined borders and a $30 \%$ excavation, preserved neuroretinal rim, central vessels without alterations, foveal irregular glistening light reflex ("cellophane"), presence of horizontal folds and applied retina. The periphery showed no alterations (Figs. 3 and 4).

An optical coherence tomography (OCT) reported no alterations in the vitreoretinal interface, retina with a 


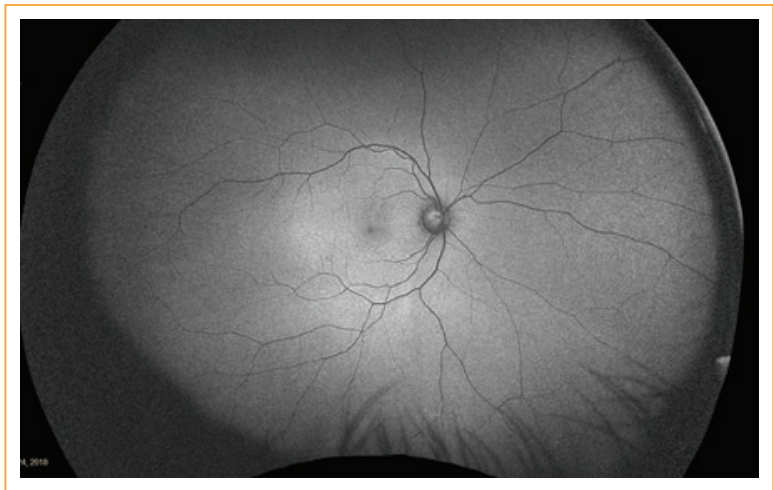

Figure 2. Optos: Autofluorescence of the right eye without alterations.

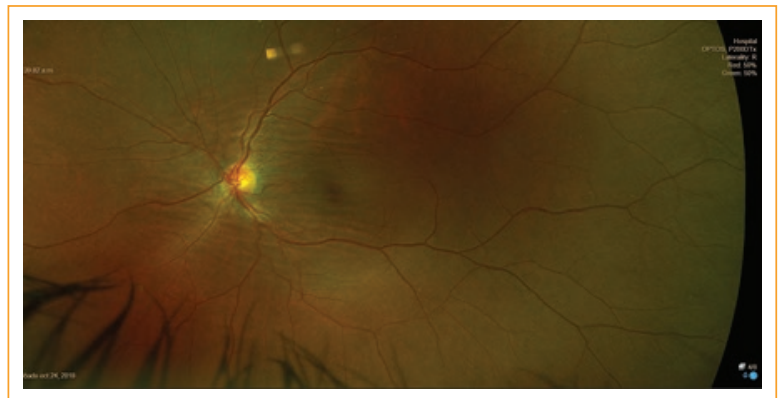

Figure 3. Optos: Horizontal lines in the fundus that correspond to folds in the posterior pole and part of the macular area.

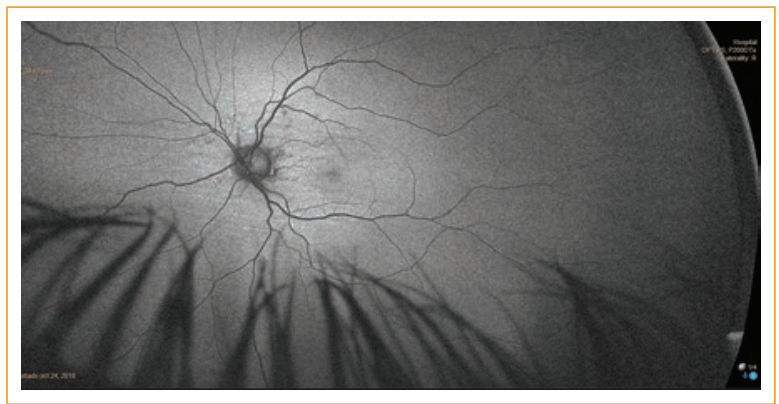

Figure 4. Optos: Autofluorescence of the left eye showing areas of irregular, horizontal, hyper- and hypo-pigmented lines that involve the posterior pole and part of the macular area.

preserved foveal profile and internal and external layers of the retina without alterations in the OD. In the OS, there were no alterations in the vitreoretinal interface, the foveal profile and retinal thickness were preserved, but the external retina and RPE showed slightly prominent undulations (Figs. 5 and 6).

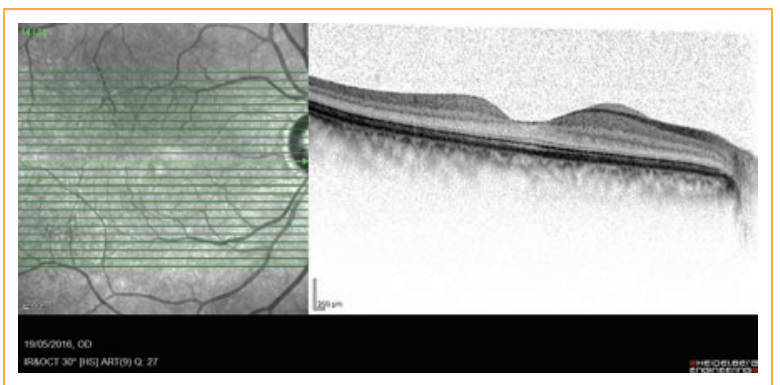

Figure 5. OCT Triton of the right eye.

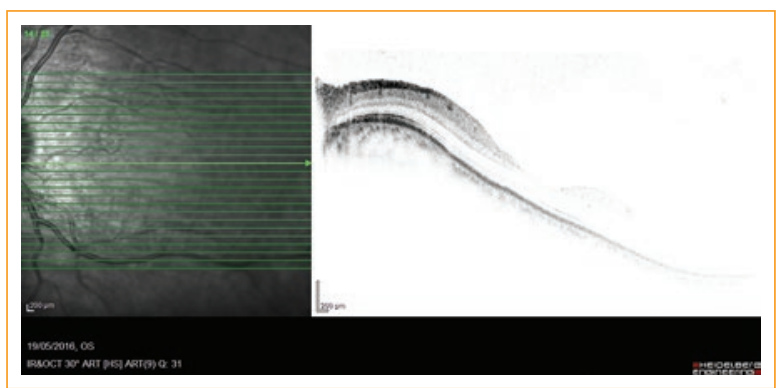

Figure 6. OCT Triton of the left eye.

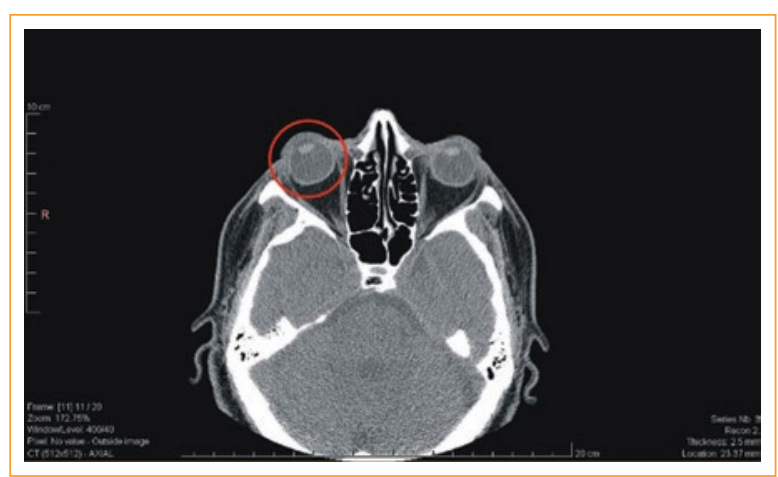

Figure 7. Axial section of skull and brain tomography. Affected eye.

Simple computed tomography (CT) images of the skull and brain did not show central nervous system alterations, but there was a flattening of the posterior wall of the globe in the left eye (Fig. 7).

Ultrasonic biometry showed an antero-posterior diameter of $23.89 \mathrm{~mm}$ for the OD and of $22.28 \mathrm{~mm}$ for the OS. An ultrasound reported no OD alterations (Fig. 8). OS by ultrasound showed a phakic globe with minimal vitreous condensations, partially detached posterior hyaloid without traction, applied retina and choroid, showing rectification of the posterior pole wall, 


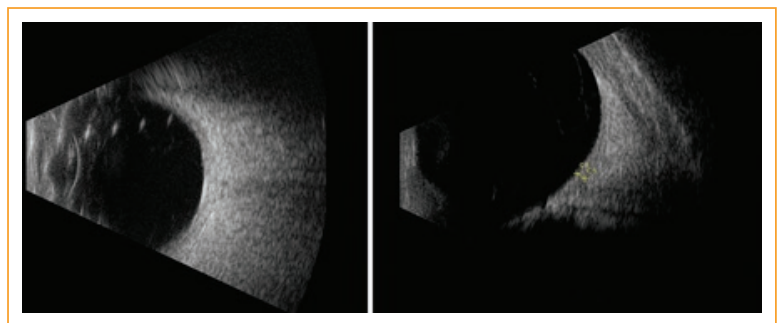

Figure 8. Ultrasound of the right eye, axial and longitudinal sections.

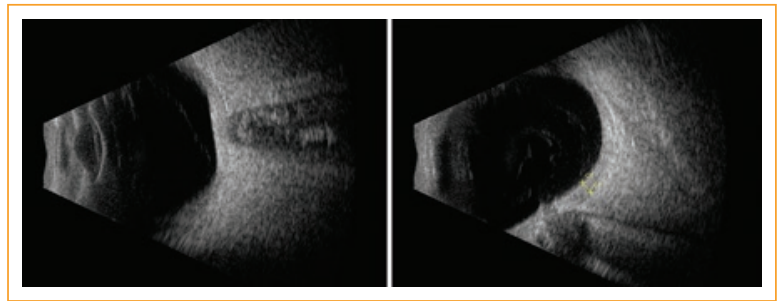

Figure 9. Ultrasound of the left eye, axial and longitudinal sections.

with a chorioretinal thickness at the macular level of $1.64 \mathrm{~mm}$, and an optic disc excavation that was not evaluable (Fig. 9).

He attended the Retina department of our hospital, where we decided only surveillance and follow-up every 6 months to assess retinal changes.

\section{Discussion}

Acquired hyperopia with choroidal folds is a disorder of unknown etiology that predominantly affects males $(14: 1)^{6}$. Once established, it shows no progression. In the fundus, choroidal folds are visualized as parallel striae, in a temporal direction, which are highlighted in the red-free image.

In some cases they may represent a congenital anomaly, but they are also considered a non-specific sign of orbital or choroidal tumors, hypotonia, papilledema, papillitis, choroiditis, uveal effusion syndrome, venous occlusion, subretinal neovascularization, intracranial hypertension, ocular or orbital inflammation, farsightedness or previous scleral surgery, such as scleral buckling. Therefore, all these disorders should be considered in the differential diagnosis?

Jacobson stated that the association between choroidal folds and hyperopia can precede papilledema.
Therefore, lumbar puncture should be considered when evaluating these patients ${ }^{7}$.

In 1980, Kalina, et al. reported a small series of six adult patients who developed symptoms associated with farsightedness and who also had choroidal folds. This report, with the long-term follow-up of these patients, confirmed the benign nature of these folds, since they all maintained a stable vision and fundus appearance $^{7}$. The same group of researchers later characterized the syndrome by describing typical CT findings, which included posterior flattening of the eyeball and widening of the subarachnoid space around the optic nerve sheaths. Since then, there have been isolated reports of cases with this unusual condition in the literature ${ }^{8}$.

The folds produce undulations on the retinal surface that are visible by biomicroscopic examination, and the characteristic by ultrasound of idiopathic choroidal folds is a flattening of the posterior wall of the eyeball, caused by a diffuse thickening of the sclera and chorioretinal layer. These eyes have a short axial length compared to the contralateral eye, and there may be ultrasound evidence of increased fluid surrounding the optic nerve ${ }^{8-11}$.

Currently, there is no treatment for this clinical entity.

\section{Conclusion}

The frequency of chorioretinal folds in the ophthalmic practice is low; age and sex are not related to their presence. In these cases, ultrasound serves as a diagnostic complement to make the definitive diagnosis.

\section{Conflicts of interest}

The authors declare no conflicts of interest.

\section{Ethical disclosures}

Protection of human and animal subjects. The authors declare that no experiments were performed on humans or animals for this study.

Confidentiality of data. The authors declare that they have followed the protocols of their work center on the publication of patient data.

Right to privacy and informed consent. The authors have obtained the written informed consent of the patients or subjects mentioned in the article. The corresponding author is in possession of this document. 


\section{References}

1. González JC, Hernández O, López D, Leal Y. Síndrome de hipermetropía adquirida con pliegues coroideos Instituto Cubano de Oftalmología "Ramón Pando Ferrer". Rev Cubana de Oftalmol. 2017;30.

2. Gass JDM. Stereoscopic atlas of macular diseases. St. Louis: Mosby; 1998. p. 204-96.

3. Hyvarinen L, Walsh FB. Benign chorioretinal folds. Am J Ophthalmol. 1970;70(1):14-7

4. Cassidy LM, Sanders MD. Choroidal folds and papilloedema. Br J Ophthalmol. 1999; 83 (10):1139-43.

5. Butler TK, Sutton G, Moshegov C, McKay DL. Uveal effusion following laser in situ keratomileusis (LASIK) for hypermetropia. Am J Ophthalmol. 2004;137(4):763-5.
6. Murdoch Franzco D, Merriman Franzco M. Acquired hyperopia with choroidal folds. Clin Experim Ophthalmol. 2002;30:292-4.

7. Paz-Moreno J, Jiménez-Parras R. Pliegues coroideos. A propósito de dos casos. Arch Soc Esp Oftalmol. 2010;85(1):38-40.

8. Orozco Gómez LP, Ramírez Estudillo JA, Lámbarry Arroyo A. Pliegues coroideos. Sección de trabajos científicos originales. Rev Mex Oftalmol. 2004;78(4):157-64.

9. Frazier S, Green RL. Ultrasound of the eye and orbit. $2 .^{a}$ ed. St. Louis: Mosby; 1992. p. 80-2.

10. Guthoff R. Ultrasound in ophthalmologic diagnosis A practical guide. New York: Thieme Medical Publishers; 1991. p. 153-4.

11. Sampaolesi R. Ultrasonidos en oftalmología. Buenos Aires: Editorial Medica Panamericana; 1984. p. 182-4. 